\title{
제2차 $\mathrm{ESCAP}$ 빈곤경감위원회 결과
}

\section{I . 핵심요지}

ㅁㅈ 2 차 $\mathrm{ESCAP}$ 빈곤경감위원회가 11.23 (수) 25(금) 3일간 일정으로 태국에서 개최되었는바, 11.23(수) 회의결과는 다음과 같음.

ㅁ 우리측은 한국의 ODA 정책관련 동향을 간략히 소 개하고, $\mathrm{ESCAP}$ 사무국이 새마을 운동사업에 대해 지속적인 관심을 기울여줄 것을 요청하였음.

\section{II. 김학수 사무총장 개회사}

아태지역은 역동적인 지역인바, 지난 수십년간 빈 곤퇴치와 관련 상당한 진전을 이룩하였음. 특히, 절대빈곤 인구의 수가 대폭 감소하고 있음.

ㅁ 그러나, 절대빈곤인구의 수가 감소하고 있음에도 불구하고 빈곤문제는 여전히 역내의 중요한 문제 이며, 특히 국가간의 격차가 큰 문제임.

\section{III. 토의내용}

\section{가. J. Mirrlee 교수(노벨경제학상 수상자) 특강}

ㅁ 빈곤을 정의하는 것은 불가하나 실용적인 목적으 로 빈곤을 측정하는 것은 여전히 중요함.

ㅁ 빈곤을 퇴치하는 방법으로는 이전(transfer)과 투 자(investment)가 있음.

- 이전(transfer)은 공공지출확대 등을 통한 소득 증대를 포함함.

- 투자(investment)는 간접적이어서 효율적이 아 닌 경우도 있음.

ㅁ 이전에는 사기 또는 부패가 수반될 수 있으나 투 자는 이러한 문제로부터 자유로움.

ㅁ 무료의료서비스, 무료교육 등이 정책적 대안으로 검토될 수 있음.

- 그러나, 이러한 서비스를 제공하기 위해서는 정 부의 수입이 증대되어야 하는 어려움이 있음. 


\section{나. 지방분권과 빈곤경감}

ㅁ인도, 파키스탄 등은 자국의 사례를 들어 지방분 권이 빈곤경감에 유익하다는 점을 강조하였음.

ㅁ 빈곤측정과 같은 분야에 있어 지방분권은 상당한 장점을 가지고 있음.

\section{다. HLP 후속조치}

ㅁ일본은 자국이 전세계 $\mathrm{ODA}$ 의 5 분의 1 에 상당하 는 부분을 제공하고 있음을 강조하면서도 국내 경 제사정상 단기간내에 $\mathrm{ODA}$ 를 대폭 확대하는 데는 어려움이 있음을 솔직히 시인하며, 사무국의 문서 내용중 부채탕감이 마치 모든 나라에 적용될 수 있는 것처럼 묘사되고 있으나 이는 사실이 아니며 최빈국에 국한되고 $\mathrm{AIB}$ 에 대해서는 다시 한번 반 대입장임을 분명히 하였음.

무이륵은 지난 2000 2004년간 ODA를 두배로 증대하였고, 향후에도 $\mathrm{ODA}$ 를 확대하기 위한 계 획을 수립중에 있으며, APCICT를 통해 역내 정보 격차해소에도 노력하고 있다고 하였음.

ㅁ 러시아는 빈곤관련 역내 통계의 갱신이 필요함을 지적하였음.

맠ㅋㅅ스탄은 선진국들이 ODA를 늘려야 한다고 하 였음.

\section{라. 빈곤경감관련 프로젝트}

일본은 ESCAP이 빈곤경감과 관련 UNHABITAT 등과도 협력을 강화할 필요가 있으며 환경과 빈곤 관련 프로젝트도 필요함을 강조하였음.

ㅁ 러시아는 민간부문을 포함하여 포괄적인 파트너
쉽이 필요하며, 빈곤경감에 경제성장이 대단히 중 요하다고 하였음.

ㅁ우리측은 새마을운동의 중요성을 강조하면서 사 무국이 동 운동관련 프로젝트를 더욱 충실히 할 것을 요청하였음.

- 상기관련, 사무국측은 금년말 동 운동관련 1단 계 프로젝트가 종료될 예정이며, 2단계 사업 추 진관련 $\mathrm{KOICA}$ 측과 접촉하고 있으며 계속적인 지원을 희망하고 있다고 하였음.

[자료:주태국 대사관] 